\title{
Gender Responsive Planning and Budgeting in the Department of Health, Department of Education and Culture, Kebumen District 2017-2019
}

\author{
Dewi Erowati ${ }^{1}$, Pudji Astuti ${ }^{2}$ \\ \{dewi.erowati@live.undip.ac.id ${ }^{1}$ \} \\ Universitas Diponegoro, Indonesia ${ }^{1,2}$
}

\begin{abstract}
This research is motivated by demand for gender equality that accommodates level of community participation and eliminates dominance of men over women in development, especially with the passage of Presidential Instruction No. 9 of 2000 on Gender Mainstreaming in National Development. It is demanded leader of institutions/ministries to integrate aspirations and experiences, the needs and problems of women, men and children in planning, implementing, monitoring and evaluating all policies, programs and activities in various fields of development. In line with the central government, local governments of Kebumen also support the program where each SKPD includes gender responsive programs. This research was taken place in Kebumen as one of the poorest districts in Central Java, with research object were the Education and Culture Office and Health Office since the two agencies most clearly included gender responsive programs. The research used method qualitative, with descriptive analysis, data collection methods in form of interviews with 6 informants, as well as literature study and observation. The finding shows that gender responsive programs in the Education and Culture Office are all gender responsive, with a budget of IDR 363,853,154,000.00 in 2017, almost 3 (three) times in 2019 to IDR 827,267,042,000.00. The Health Office only has one program, namely the prevention of HIV/AIDS, with the budget experiencing a significant increase, namely IDR 26,013,000.00 in 2017, to IDR 177,128,000.00 in 2018 and in 2019 IDR $316,615,000.00$. The size of the budget shows that policy makers understand the program with government programs. It shows that Kebumen District are care about gender responsive programs.
\end{abstract}

Keywords: Gender, Gender Responsive Planning and Budgeting, Department of Health, Department of Education and Culture, Kebumen District

\section{Introduction}

This research is based on the demand for major changes related to gender relations, namely a relationship that requires equal roles of men and women in the life of society, nation and state, in the millennium era. The demand for equality of roles can be seen as a form of necessity that accommodates the level of community participation and eliminates the domination of men over women in development. The existence of a form of role domination that has occurred so far is the cause of low participation women in the public sphere. This condition does not benefit to women who have a strategic role in various fields such as education, health, socio-culture, economics and so on. Especially if you look at the conditions in Indonesia, women are still lack in giving their participation both in energy and in mind. 
This is of course contrary to human rights, namely the rights to life because they also human in nature. Every human being regardless of his nature has a need to fulfil his rights, so equal rights to life are needed with obligations. The basis is that there is no difference shown between men and women because there is no difference that is meant, all have equal rights and obligations.

In order to respond to gender issues, the Indonesian government has paid more attention since the issuance or ratification of Presidential Instruction (Inpres) Number 9 of 2000 concerning Gender Mainstreaming in National Development. At that time President Abdurrahman Wahid, who is commonly known as "Gus Dur" instructed leaders of agencies/ministries to integrate aspirations, experiences, needs and problems of women, men, and children in planning, implementing, monitoring and evaluating all policies, programs and activities in various fields of development. The birth of Inpres was a political strategy or a political issue because of the political will, the government had to include gender equality as one of its main objectives. In other words, the government conveyed its mission to include a gender perspective in all policies, programs or activities that should aim at gender equality. At the same time as the PUG Inpres was born, discussions were also taking place regarding the 1945 Constitution Amendment. The 1945 Amendment led to constitutional changes in Indonesia, one of which was regarding national development planning, with the promulgation of Law No. 25 of 2004 concerning the Development Planning National System (SPPN), a year earlier the State Finance Law was passed, namely Law No. 17 of 2003 [1].

Gender responsive planning and budgeting is a plan that is prepared by consideration of four aspects, namely access, participation, control, and benefits that are received equally between men and women [2][3]. This means that every gender responsive planning and budgeting takes into account the aspirations, needs, and problems of both men and women who are the same, equally in the process of program or activity formulation and implementation of the program or activity.

If it is related to planning and budgeting process after the enactment of the SPPN Law, then each ministry or agency $(\mathrm{K} / \mathrm{L})$ makes a Strategic Plan (Renstra) based on the RPJMN (National Medium-Term Development Plan) and its indication. The Strategic Plan contains vision, mission, objectives, strategies, policies, programs and development activities in accordance with the duties and functions of the Ministries/Agencies. After the K/L's Renstra is formed, each $\mathrm{K} / \mathrm{L}$ prepares a Work Plan (Renja $\mathrm{K} / \mathrm{L}$ ) based on the $\mathrm{K} / \mathrm{L}$ Renstra and refers to national development priorities and indicative ceilings, and contains policies, programs and development activities that are well implemented, directly by the government or by encouraging community participation.

The same process also happening in the regions level. SKPD Strategic Planning (Regional Work Unit) is guided by the RPJMD (Regional Medium-Term Development Plan) and is indicative in nature, containing the vision, mission, objectives, strategies, policies, programs and development activities that are prepared in accordance with the SKPD's duties and functions (tupoksi). After all, compilation of the SKPD Renja as referring to the SKPD Strategic Plan and the RKP containing policies, programs and development activities are implemented by the local government or those pursued by encouraging community participation.

Gender responsive planning and budgeting is not a separate budget between men and women but focuses more on gender equality and justice in both national and regional planning and budgets. However, there are still many bureaucrats who do not understand gender responsive planning and budgeting. This is of course an issue that should be addressed in governance in Indonesia, so that each $\mathrm{K} / \mathrm{L}$ and local governments make programs and 
implement gender responsive programs. Research on gender-responsive planning and budgeting is needed, considering that meeting the needs of men and women is very important. However, in practice there are still many gaps or gaps in the budget allocated for programs in each SKPD, resulting in inequality between men and women in the development process.

Central Java province consists of 29 districts and 6 cities. Kebumen Regency is a district with a poor category in Central Java. In connection with the national strategy on PUG, this research will look at whether Kebumen District also accommodates gender responsive planning and budgeting. The question research is how gender responsive planning and budgeting in Kebumen District 2017-2019? What strategies are implemented in realizing gender responsive programs in Kebumen District?

\section{Methodology}

The novelty of this research lies in the programs and budgets in the Education and Culture Office, as well as the Health Office. Previous research looked at the overall budget in the APBD. The theory used is Budlender's theory of gender responsive budget understanding. This research is a qualitative description, with descriptive analysis. The keynote speakers were Herman, Dapodik staff/basic education data, Eko Budiyono, head of the planning sub-division of the Education and Culture office, Maryati, the health office executive staff, Ani Marlina, a junior high school teacher/a contract-based teacher, Neny Liana, a civil servant teacher at SMKN 1 Kebumen, Lala, a junior high school student. Apart from interviews, other data collection is done with research libraries. The data test used triangulation, namely crosschecking data from several sources with secondary data. The theory used is the concept of gender and gender responsive budgeting.

\section{Results and Discussion}

The policy basis is in the form of Presidential Instruction No. 9 of 2000 on Gender Mainstreaming (PUG). The goal of PUG is gender equality and justice, which is a condition in which portion and social cycle of women and men are equal and balanced, especially their involvement in the development process. The policy direction for increasing gender equality is outlined in the 2016-2021 RPJMD document for Kebumen Regency. The gender responsive program at the Health Office, namely the Prevention and Control Program of Infectious Diseases, namely HIV/AIDS. This program is a national program, so it must be implemented every year in 2017, 2018 and 2019. The Prevention and Prevention Program of Infectious Diseases, namely HIV/AIDS, is run by the Kebumen District Health Office by providing HR facilities, providing these HR facilities, namely VCT services which aim for screening people at risk. The people at risk are categorized into two, namely the special population and the general population. The special population consisted of pregnant women, TB patients, STI patients, and hepatitis B while the general population consisted of MSM, Waria and CSWs. Both the special population and the general population are targets that must be addressed by the Kebumen District Health Office. In the examination, the Health Office uses triple elimination so every pregnant woman is required to check for HIV/AIDS, syphilis, and hepatitis. The purpose of the examination is to break the link so that the baby who is born is not exposed to syphilis because pregnant women who suffer from syphilis will have a 
miscarriage or their child will be a disable person, and so on. Then hepatitis B so that pregnant women do not get hepatitis B, as well as testing for HIV/AIDS. Even though we have used triple elimination in its arrangement, there are still a lot of unwanted events due to the late detection of pregnant women in Kebumen Regency.

The budget for implementing the HIV/AIDS program, according to Maryati, is around IDR 300,000,000.00 with funding sources from PAD/DAU. After cross-checking, the budget for prevention and control of HIV/AIDS in 2017 is IDR 26,013,000.00. Whereas for 2018 the budget that was specifically given for HIV/AIDS in 2018 was IDR 177,128,000.00 while for 2019 it was IDR 316,615,000.00. This indicates that related service staff is not understand how much budget is allocated to implement gender responsive programs. The increase in the DHO budget in a gender responsive program indicates that the availability and budget allocation was better than the previous year to meet the increased program needs.

The basis for planning a gender responsive program, in this case the Health Office HIV/AIDS, namely SPM or Minimum Service Standards. The Health Office has targets, among others, pregnant women are required to test for HIV by requesting data from KIA while CSWs request data from the outreach. In determining the target, the Health Office looks at the previous year. For example, if the previous year can be examined 100, then for the following year it is also given a target of 100 .

Programs implemented to realize gender responsive programs in the Education and Culture Office are by applying them to all programs. This was conveyed by the Head of the Planning Subdivision of the Education and Culture Office of Kebumen Regency that every program implemented at the Education and Culture Office of Kebumen Regency implements gender responsiveness, for example, the new school year, namely the acceptance of new students. When the admission of new students, there is no difference regarding gender, both male and female. Female students and male students have the same opportunity and are not limited unless it is not in accordance with the provisions. However, if seen from the 2017 RKPD, there is a non-formal education policy development program sourced from Provincial Assistance, namely the implementation of gender mainstreaming (PUG) with a target of 40 people (toga, Thomas, PAUD, SD, SMP educators) with a funding requirement of IDR $50,000,000$. Whereas for the following year in the RKPD both years. In 2018 and 2019, there are no activities to carry out gender mainstreaming. Therefore, the Education and Culture Office explained that all programs in the Education and Culture Office are gender responsive. Regarding the budget, the Education Office in 2017 based on the Regional Work Unit Budget Implementation Document has a budget of IDR $363,853,154,000$, in 2018 IDR $340,396,148,000$ and in 2019 IDR 827,267,042,000. Meanwhile, the strategy for implementing gender responsive planning and budgeting for both the Health Office and the Culture and Education Office of Kebumen Regency in 2017-2019 does not have a specific strategy, only implementing all the plans contained in the Health Service Strategic Plan and the 2016-2021 Education and Culture Office Renstra. The Health Office only has one program, namely the prevention of HIV/AIDS, besides being a national program, Kebumen also has a large number of HIV/AIDS sufferers, namely 182 people in 2017, then decreased to 150 people in 2018 and decreased to 127 people in 2019 This shows success in reducing HIV/AIDS sufferers, meaning that the gender responsive program is right on target as evidenced by the reduction in the number of HIV/AIDS sufferers. Meanwhile, all programs of the Education and Culture Office are gender responsive. This fact shows the government's commitment to implementing gender responsive budgets properly, even though Kebumen Kebumen is one of the poorest districts in Central Java. 


\section{Conclusion}

Although the Health Office only has one gender responsive program, maximum budget absorption is reached and the result of prevention program to HIV/AIDS is significantly achieved. Moreover, all the program at the Office of Education and Cultural were already gender responsive scheme. It shows a great care from local government of Kebumen in order to implement the program. Also, a significant increasing number of budgets reveals a good will of local government to execute a gender-based budget.

\section{References}

[1] D. Erowati, "Politik Perencanaan Pembangunan Nasional Era Pemerintahan Susilo Bambang YudhoyonoJusuf Kalla (2004-2009)," Universitas Indonesia, 2017.

[2] R. N. Nugroho, Gender dan strategi pengarus-utamaannya di Indonesia. Pustaka Pelajar, 2008.

[3] D. Remiswal, S. AG, and M. Pd, "Menggugah Partisipasi Gender di Lingkungan Komunitas Lokal," Yogyakarta Graha Ilmu, 2013 